This is the version of the article accepted for publication in European Journal of Marketing, 46 (6). pp. 1233-1251 published by Emerald https://doi.org/10.1108/03090561211247810

Re-use is subject to the publisher's terms and conditions

Accepted version downloaded from SOAS Research Online: http://eprints.soas.ac.uk/21660

\title{
Examining the Relationship between Brand Emotion and Brand Extension among Supporters of Professional Football Clubs
}

Purpose: There is debate and controversy about the use of branding in sport. Often, fans show loyalty to their club that many brands could only dream of, and a key argument of previous research is that supporters do not like to think of their club in commercial terms, as a brand (Chadwick and Beech, 2007; Chadwick and Holt, 2006). However, we argue that in today's environment fans have a pragmatic attitude towards the necessity of branding and its importance in the future success of their clubs. Thus a model conceptualising the relationship between supporters' emotional attachment, supporters' brand perception/strength and their support for brand extension was developed and tested.

Methodology: In-depth interviews with, players, clubs' officials and supporters, leading to the design of a survey instrument completed by 852 supporters of two professional Norwegian football clubs.

Findings: The model confirms that fans that have a strong emotional attachment to their club have a stronger perception of the club as a brand and support brand extension.

Research limitations: This is a one country study.

Practical implications: Club management needs to be careful when extending its brand. Brand extension must be designed to reflect the heritage and tradition of the club. Also, club management needs to show in brand extension an element of competitiveness which improves brand image, strengthens supporters' belief in their club and attracts new supporters.

Originality/value: We provide new evidence which contradicts existing theory. The study challenged the widely accepted argument that supporters of football clubs are likely to disapprove of and reject the thought of their favourite football club as a brand.

Keywords: Brand, Brand emotion, Brand Extension, Sport Marketing. 


\section{Introduction}

The use of branding as a business tool has become increasingly important in today's competitive and hostile business environment. Although marketing and branding are increasingly important in the business of sport, research lags behind this development, particularly in Europe (Ferrand and Pages, 1999). The North American market differs considerably from that of Europe. North American sports clubs are often franchises and can be moved around the country at the whim of their owners, for example, a situation that many European fans would consider shocking. Furthermore, much of the present research on the marketing and branding of professional football in Europe focuses on what Desbordes (2006) refers to as the 'big five' markets: England, France, Germany, Italy and Spain (e.g. Bauer et al., 2005; Couvelaere and Richelieu, 2005; Ferrand and Pages, 1999; Guenzi and Nocco, 2006; Hill and Vincent, 2006). Because these nations' clubs and leagues are competing at a considerably different level than the rest of Europe, both commercially and competitively, the findings from previous research might not necessarily be applicable to clubs competing in the smaller European football nations. Hence, this research aims to bridge this gap in the literature by focusing on how professional football clubs are reacting to the challenge of branding their clubs. Can branding help clubs in smaller football markets to survive and prosper or is it inappropriate and likely to alienate key stakeholders, e.g. supporters?

The sports marketing literature suggests that consumers of sports 'brands' (i.e. supporters) have unique relationships with their favourite sports teams. However, Chadwick and Beech (2007) and Chadwick and Holt (2006) argue that supporters are likely to disapprove of and reject the thought of their favourite football club as a brand. The authors state that sport is often consumed in an irrational rather than rational, economic manner. Chadwick and Beech (2007) are critical of much sport marketing activity saying that it is often sales oriented reduced to a drive to fill corporate boxes and sell perimeter advertising space. Supporters do not like to think of their club being sullied by commercialism. Many are appalled at the thought of their club (and all it represents) being reduced to no more than a brand. This is due to the extremely close relationship that the fan has with his/her club (Jones, 1997), the importance of local identity and family history in the decision of which club to support, the relationship between the football club and the supporter's identity and self-image (Westerbeek and Smith, 2003). The high level of identification (Underwood et al, 2001) that supporters have with their team makes them more sensitive to the over-commercialisation of 
something they have a unique emotional bond with (Conn, 1998). However, attendance at professional football matches is now a part of the entertainment industry and many other options are competing for the fans' money. Do supporters of smaller clubs, therefore, accept that branding and strategic branding activity is a necessity to ensure the survival and growth of their clubs?

Academic studies within the field of sports branding have so far been limited to the area of brand equity (e.g. Bauer et al., 2005; Gladden, Sutton and Milne, 1998; Ross, 2006) and brand extensions (e.g. Apostolopoulou, 2002; Chadwick and Clowes, 1998), and little research has examined the relationship between supporters' emotional attachment, supporters' brand perception/ strength (that is whether or not supporters perceive their club as a brand) and how this relates to their support for brand extension. Given the lack of brand research in a European sporting context, this study will examine the role of supporters' emotion and identity on the perception of a football club as a brand and their attitude towards overt branding activity by their clubs, namely, brand extension.

\section{Branding}

A brand's identity is constructed by the attributes that arise in a person's mind when a brand is mentioned (Rein et al., 2006). Hence, as Calkins (2003) proposes, branding has essentially to do with the creation of a perception and positioning in the minds of the consumers. de Chernatony (2003) argues that brands are clusters of functional and emotional values which promise stakeholders unique experiences. Emotional values can potentially represent a source of sustainable competitive advantage (de Chernatony, 2003). Brands are rarely only about the physical attributes, but rather a set of values and a philosophy that can be matched with the consumers' own values and philosophy (Brassington and Pettitt, 2004). As Kapferer (1997, p. 17) proposes, the brand is not the product, but it "gives the product meaning and defines its identity both in time and space." Differentiating a brand in terms of functional values is often attractive because such values are relatively concrete and can therefore be communicated to consumers simply and clearly (Tybout and Sternthal, 2003). However, the functional values are argued to be less sustainable than the emotional ones, and emotional values can potentially represent a source of sustainable competitive advantage (de Chernatony, 2003). It is evident that the marketer initiates the branding process, which de Chernatony and McDonald (2003) refer to as the input process of branding. However, it is wrong to assume 
that branding is something that is done to customers. Consumers are not just passive receivers of marketing information; they are active in the production of meaning and do things with marketing messages (Brown, 2003; de Chernatony and McDonald, 2003). In that sense, consumers become co-creators of the brand's messages and meanings (Brown, Kozinets and Sherry, 2003). Consumers form a mental vision of a brand, which is regarded as an output (de Chernatony and McDonald, 2003, p. 25). This mental vision, known as a brand image, may sometimes be different than the intended marketing objectives (Noble, 2006).

\section{The Uniqueness of the Sports 'Brand' and Importance of Emotion}

Bourke (2006) suggests sport marketing has unique characteristics and considerations not found in most areas of product marketing. Indeed, even allowing for the intangibility of many service offerings, spectator sports still present unique difficulties. It is an offering that is highly inconsistent from one consumption experience to another and the marketer typically has very little control over the core product - the sporting event itself (Mullin, Hardy and Sutton, 2000). A football match played today will be different from the previous week's match even if the starting squad is the same. Yet, despite these unfriendly characteristics, the sports product is highly sought by consumers (Pons and Standifird, 2006). The supporter is very often involved in creating the service; hence, they become 'pro-sumers' of the sporting experience (Cherubini, 2006, p. 111). They may have a very positive influence, such as the creation of the atmosphere inside the stadium, generating excitement for other spectators or, conversely, a negative influence if they are involved in violent incidents or pitch invasions.

Westerbeek and Smith (2003) argue that sport watching cannot be reduced to an exercise in cost-benefit analysis. They argue that not only is sport a social experience, but it is also a highly personal one, often bound up with identity and self-image. This is supported by Chadwick and Beech (2007) who suggest that sport is often consumed in an irrational, rather than a rational, economic way. Logically, if a product consistently fails to live up to its expectations, people will stop buying it (Parker and Trish, 1997). In sport, however, this is not always the case. A study by Fisher and Wakefield (1998) found that fan motivation and subsequent behaviour seemed unrelated to a sports team's performance. Indeed, Hunt, Bristol, and Bashaw (1999) propose that fan behaviour is often mentioned by managers and players as a determinant rather than an outcome of team performance. The sports brand (as with other corporate brands) has multiple stakeholders that it must satisfy, including 
supporters, television companies, the local community and sponsors (Mason, 1999). The fact that professional sport must market itself to these diverse groups means that a strong and relevant brand could potentially increase the commercial value of the sports organisation and create a virtuous circle leading to increased revenues from commercial activities for the club. Of course the club brand also operates within its own league structure and therefore must simultaneously compete and co-operate with other clubs in the same league, it cannot exist in isolation.

Sports are typically characterised by a high degree of consumer commitment and emotional involvement, which make the opportunity to build brands and strong relationships with consumers of sport possible (Sutton et al. 1997). Underwood et al. (2001) proposed that spectator sports provide an increasingly rare sense of community in today's rapidly disconnecting society, providing common symbols, a collective identity and a reason for solidarity. Spectator sports are a unique group experience characterised by a sense of belonging that supporters feel and an inherent bias against out-of-group members (Hunt et al., 1999). Since each supporter and participant create a different perception, managing the sports brand becomes extremely difficult for the sport marketer (Ross, 2006). Spectator sport supporters are not a homogenous group with similar needs and motivations. Any match is likely to draw several typologies of sports fans with identifiably different and changing market segments (e.g. Hunt et al., 1999; Tapp and Clowes, 2002).

Professional sports clubs also have considerable cultural importance, and are often highly embedded into the local culture from where they originate. A study by Jones (1997 cited in Hunt et al., 1999, p. 444) found that the two most frequently mentioned reasons for supporting their favourite football club were that it was the local team (53 percent) and that the supporter was born in the town (10 percent). Amongst mainstream brands, Kapferer (2002) argues that a local brand can have considerable value due to the deep-rooted and powerful bonds forged with local consumers. For instance, very often people tend to buy a local brand because their parents bought it, a relationship based on confidence and loyalty created by personal attachment (Kapferer, 2001). This is also very evident amongst sports teams. Hunt et al. (1999) propose that parents' or siblings' preferences may have a strong influence on a child's predisposition to become a supporter of a particular sport, team, or player. Family history often dictates that support for a club is 'handed down' from generation to generation. In such a situation the sports brand will have far greater emotional resonance 
and therefore engender greater loyalty than other commercial brands. Consumers of sports often see the product offering as an extension of themselves (Cialdini et al, 1976) and sport generates a degree of passion unheard of in relation to other products and services (Chadwick and Beech, 2007). Whannel (1992) argues that sports' ability to provide drama, excitement and euphoria and conversely frustration, annoyance and depression, the very uncertainty of it provides its characteristic intensity and uniqueness from other areas of brand consumption.

\section{Extending Sports Brands}

Many of the pressures facing sports organisations in the $21^{\text {st }}$ century - the need to increase profits and to strengthen their relationships with their fans - have forced sports organisations to look for new sources of revenue. One way of doing this has been through the introduction of new products or services; i.e. extending their brands. From a financial perspective, sports organisations have realised the equity that exists in their brand names, which can be translated into financial success in other activities that the sports organisation undertakes (Apostolopoulou and Gladden, 2007). In Mullin et al.'s (2000) discussion of the sports product, they argue that the core product consists of (1) the players and coaches, (2) the venue, (3) the equipment used, and (4) the rules of the game. From that point, everything else that the sports organisation undertakes can be considered extensions. These include branded merchandise, food and beverage, match day programmes, executive hospitality, or anything that may help extend the experience of the fans.

Keller (2003) argues that one way to grow a brand and to maintain brand equity is through brand extension strategies. He suggests that brand extensions can be used to revive a brand and to "renew interest and liking" for the brand (p. 589). Sports organisations may not introduce brand extensions solely for the revenue they generate. According to Apostolopoulou (2002), brand extensions are often used to connect the parent brand with core customers, expand its reach, enhance its presence in the community, strengthen a positive image, and give people more opportunities to experience the brand. The wider marketing literature suggests that introducing a new product under an existing brand name can be beneficial in a number of ways. Customers can use prior knowledge of and experience with an existing brand to assess an extension of that brand (Keller, 2003). The positive associations that customers have of a parent brand may transfer to the extension, even more so if there is a strongly perceived fit between the two products or services (Aaker and Keller, 
1990). It may also benefit the parent brand; if a customer has a good experience with the extension, it may lead to positive associations towards the parent brand or bring the company new customers who had no past experience with the parent brand (Martínez and de Chernatony, 2004; Keller, 2003). In the case of sports brands, in which fans already have an established relationship with a particular club and demonstrate varying degrees of fan identification, extensions can provide new opportunities for fans to interact with the club and reinforce their sense of fan identity and belonging (Apostolopoulou, 2002; Sutton et al., 1997). Fan identification will impact upon the success of extension strategies as well. Research by Wann and Branscombe (1993) found that supporters with high degrees of identification are more willing to spend money and time to follow a sports club, a behaviour that was also found with regards to spending money on brand extensions (Tapp and Clowes, 2002).

\section{The Theoretical Debate}

As discussed, the sports marketing literature suggests that consumers of sports 'brands' (i.e. supporters) have unique relationships towards their favourite sports teams. According to the literature, supporters are likely to disapprove of and reject the thought of their favourite football club as a brand. Chadwick and Holt (2006) refer to the McDonaldisation of the sports experience. Apostolopoulou (2002) argues that supporters may have difficulty in accepting that 'their' club's name and logo appear on products that seem unrelated to sport and this may frustrate their relationship with the club. Chadwick and Beech (2007) state that supporters frequently react with disdain when faced with the commercial exploitation of sports brands. It is interesting to note the creation of a new football club in England, FC United of Manchester by supporters of Manchester United disillusioned with the over commercialisation of their club. However, such reactions may be culturally dependent and certain supporter segments may be more positive towards brand extensions than others (Tapp and Clowes, 2002). Furthermore, Dacin and Smith (1994) argue that a brand can be associated with a number of products without being diluted as long as there is high quality across those products.

We feel that the growing commercialisation of football has led supporters to see the benefits to their club of branding, especially if they wish their club to grow and compete at a higher level. Football clubs are competing not just with each other but with the many other leisure choices that the consumer has upon which to spend their money and the continued marketing 
activity necessary to recruit and retain fans is essential (Rein et al (2006). Supporters are realistic in surmising that the wealthier the club, the better players it will be able to afford and the more competitive it will be. The time when football was almost totally free of commercial connections seems further and further away. In such circumstances it is logical that supporters accept the visible manifestations of branding activity, namely extensions as being in their own and the club's best interests.

A number of studies found that the process of consumer evaluation of brands involves positive emotional attachment which enhances the strength of brand perception (Ruth, 2001; Thomson, MacInnes and Park, 2005). Elliott and Percy (2007) argue that when a person recalls a brand from memory they not only considered its benefits or features but more importantly their emotional feeling about the brand. Furthermore, consumer's emotional attachment to a brand induces a state of emotion-laden mental readiness that influences his or her allocation of emotion toward a brand (Park and Macinnis, 2006). Ruth (2001, p. 99) argued that "a brand's emotional benefits can influence consumers' beliefs about the brand". Carroll and Ahuvia (2006) discuss 'brand love' for brands that offer more to the consumer in terms of symbolic benefits. Intense emotional attachments can be formed with 'love objects' and this builds on Fournier's work (1998) noting the importance of love in consumer's longterm relationship with brands. Carroll and Ahuvia report that brand love does not require either expectancy or disconfirmation; brand love involves "the integration of the brand into the consumer's identity" (p81). This reinforces attachment theory in psychology (Bowlby, 1979) suggesting that consumers can become emotionally attached to objects, including brands. There is considerable theory that relates emotional attachment with strong brands. Football is an area of life that arouses considerable emotion. Therefore, unlike Chadwick and Beech (2007) and Chadwick and Holt (2006) we argue that a strong emotional attachment can result in a stronger perception of a football club's brand.

H1. The stronger supporters' emotional attachment to their club the stronger their perception of the club as a brand

Keller and Aaker (1992) make the argument that strong brands stretch further than average brands. The assumption is that an 'affect-transfer process' will take place, that is the affect associated with the original brand will be transferred to the brand extension (Boush and Loken, 1991). Consumers are willing to try brand extensions as long as the brand is perceived 
to be of high quality and there is a clear link to the original brand (McWilliam, 1993; Reast, 2005). However, Broniarczyk and Alba, (1994) state that the evaluation of a brand extension need not directly relate to the evaluation of the brand in its original category. In relation to football clubs, Apostolopoulou and Gladden (2007) propose that, by providing more opportunities to supporters to experience the club, extensions may enhance the symbolic (e.g. fan identification) and experiential (e.g. nostalgia) benefits supporters receive from their interaction with the sports organisation. Therefore, given the strong perception that typically exists amongst supporters for their football club brands and the theoretical discussion above, we argue:

H2. A positive perception of the club as a brand will make supporters more positive towards the club's brand extensions.

Take in Figure 1 here

\section{Methodology}

There are 14 professional clubs in the Norwegian domestic league (Tippeligaen). Two clubs were chosen to reflect two distinct cases to ensure 'maximum variation' between the cases (Miles and Huberman, 1994, p. 28), with differences based on: on-field sporting success, geographical location, market size, competitive pressures, and business format and structure. There follows a brief description of the chosen clubs.

\section{Club1: Tromsø Idrettslag (TIL)}

Tromsø Idrettslag was established in 1920, and is located in the eighth largest city in Norway, Tromsø, with a population of 63,596. Being the only elite league club situated in Northern Norway, the closest direct competitor, in the form of another Tippeliga club, is Rosenborg BK, located $1,200 \mathrm{~km}$ southwards in Trondheim. TIL is a football-only sports organisation, consisting of a senior section with three teams - regular professionals, Junior A and B - and a youth section with 52 unisex teams from the age of six to 16 years old. The club has never won the Norwegian elite league, but has won the Norwegian Cup twice (lastly in 1996). 


\section{Club 2: Vålerenga Idrettsforening (VIF)}

Vålerenga Idrettsforening was established in 1913, and is located in Oslo with a population of 538,411 . Being located in the capital of Norway, the club has a large number of both direct and indirect competitors in the local area, including three other Tippeliga clubs, as well as other sports and leisure activities. VIF has a number of different sports under the 'Vålerenga' brand: ice hockey, American football, handball, and hockey, all of which are played in their respective domestic elite leagues. VIF has won the Norwegian elite league five times (lastly in 2005) and the Norwegian Cup three times (lastly in 2002).

\section{Research Design}

Prior to the development of the quantitative instrument, we conducted in-depth interviews with managers and directors of marketing, communications, and media relations in both clubs. Interviews with the organisations' decision makers were held to determine the role of branding and the implementation of brand strategy within each club. These interviews lasted from 55 to 80 minutes on the site of the respective club and were audio recorded and transcribed. To ensure the accuracy of the interview data managers were re-contacted after the interviews by email or telephone to verify the content. Similarly to interviews with toplevel management, interviews with employees, players and fans were semi-structured, designed to explore pre-determined areas, and also to allow for further investigation of relevant topics that may emerge during the interview. Interviews lasted from 10 to 30 minutes, and were audio recorded and subsequently transcribed. The main focus of these interviews was to explore the employees', players' and fans' experiences and perceptions of the club, its values, its relevance and the role of branding and brand management within the football clubs. Interviews with players also focused on understanding their perceptions of themselves as elements of the football clubs' brands. Three players were interviewed at each club and 12 interviews were completed with lower tier employees (seven at VIF and five at TIL). We further conducted 13 semi-structured interviews from fans of both clubs. A key objective of the qualitative research was investigating whether or not employees, players and fans perceived their clubs as commercial brands and the extent to which branding had been recognised and accepted by supporters. The corporate branding literature tells us that in order to convince external audiences of the worth of your brand, an organisation must first convince its internal stakeholders (Roper and Davies, 2007). The interviews with the players and staff were content analysed by theme and topic, the data was reduced into themes through 
a process of coding (Creswell, 2007). These interviews were analysed through the application of QSR n Vivo.

Following the qualitative stage, the questionnaire was designed to primarily test the above model (Figure 1) from the perspective of a key stakeholder group, supporters. The first section of the questionnaire was designed to obtain demographic and behavioural data from the respondents, whereas the second part of the questionnaire was a series of statements (19 items). These items were measured on a five-point Likert-scale with the endpoints being (1) 'Strongly disagree' and (5) 'Strongly agree' (Webb, 2003, p. 188). Following the qualitative stage in which employees endorsed the concept of the clubs as brands (see below the findings from the interviews) the 19 statements focused on exploring fans' attitudes and perceptions towards the two clubs as commercial brands.

Constructs were measured using different scales. Items measuring emotional attachment were adopted and modified from a study by Bauer et al. (2005) which focuses on the sports industry. These items reflect fans' emotional attachment related to the importance of club's logo, regional importance, nostalgia, history and tradition. Items measuring attitude to brand extension were generated from qualitative interviews. For example, club employees remarked "we have VIF water, VIF Coffee, so there are many places where we put our brand", and "there is no doubt that in Oslo VIF is just as strong a brand as commercial ones". Brand strength was measured using an overall measure stating "I think VIF/TIL is a strong brand". Furthermore, statements were included to explore (1) supporters' attitudes towards brand extensions, (2) attitudes towards the clubs as brands, (3) the perceived strength of the clubs' brands and (4) uniqueness/differentiation of the clubs' brands. The research instrument was designed to provide an overall picture of the identity of the two clubs' brands.

To check face validity, the questionnaire was pre-tested by a small sample $(n=8)$. Test respondents were given instructions to pre-use the online questionnaire and indicate potential problems in terms of clarity and understanding. This process resulted in some minor changes in wording. The questionnaire was also reviewed by another academic and presented to each of the football clubs for final approval. These processes reinforced the validity of the research instrument. The questionnaire was first designed in English then translated into Norwegian. The translation was checked by a Norwegian independent person who had a university degree in English and had spent a year studying in the United Kingdom. 
A second round of interviews was conducted with the club's supporters to further validate the quantitative findings. The interviews with both club's supporters involved two stages of data analysis. The first stage involved an immediate identification of themes during and immediately after each interview. Notes were made of common reoccurring themes between and within the interviews. These themes were reviewed and discussed independently by three academics in Norway and the UK. Themes that had full agreement among the three academics were retained.

\section{Sampling and Data Collection}

Data were collected using two sampling techniques. Firstly, online data collection was utilised, as it is cost effective when attempting to reach large-scale sample sizes in a wide geographic region (Bauer et al., 2005). Distribution of the questionnaire was supported by the two football clubs, who presented a direct link from their websites to the survey for a twoweek period at VIF and a one-week period at TIL. Secondly, snowball sampling was used, whereby a link to the online survey was emailed to an initial group of respondents who possessed the desired characteristics of the target population, and the respondents were encouraged to forward the email to others who also belonged to the target population of interest (Malhotra and Birks, 2006), i.e. supporters of each respective football club. The major advantage of snowball sampling is that it substantially increases the likelihood of locating the desired characteristic in the population (Biemacki and Waldorf, 1981). During the surveys' Internet runs, 1,012 (661 for TIL and 351 for VIF) accessed the questionnaires and attempted to complete them. After having cleaned the data, a set of 496 questionnaires for TIL and 346 questionnaires for VIF were utilised for further analysis.

Qualitative Findings - a brief overview

The main purpose of this paper is to investigate the attitudes of supporters towards branding activity. The key themes that emerged from the qualitative work were 'tradition and history', 'emotional attachment', 'club as a brand' and 'brand extension and the importance of commercialisation for football clubs'. Brief examples of these themes are demonstrated below: 


\section{a) Club as Brand}

The brand was a signifier of the relationship that people have with their club. Executives at both clubs were clear that a key objective for them was the development and strengthening of their clubs' brand. Internal brand analysis had taken place and values that underpinned the brands developed. Players and more junior staff were able to enunciate these values when questioned. It was apparent that employees of both clubs explicitly expressed that they were brands. They perceived being a brand as a positive entity and several respondents argued that their club was

"one of the strongest brands in Norway".

VIF's media manager proposed

“..it [the club] is a brand as long as you operate a commercial entity and turnover NKr $100 \mathrm{~m}[£ 8.5 \mathrm{~m}]$ a year...in that sense it cannot be anything else than a brand”.

This was reinforced by the supporters. One supporter of TIL further confirmed the above statement

"a strong brand all across Northern Norway."

One supporter of VIF also thinks of the club as a strong brand

"I think VIF is perhaps one of the strongest brands in Norwegian sports. The club is based in the capital city of Norway and has both soul and history."

The importance of the brand was recognised also by the playing staff

"as a player in VIF you are a visible person...I have to behave according to those values the club has... and support the attitudes that the club has".

And a player at TIL 
"I think it is fine. It is part of my job, and I have no problems with it. It is just positive for the club that we can contribute".

b) Tradition and History

Although respondents were happy to describe their clubs as brands, they were keen to emphasise the importance of maintaining the reputation, history, traditions, and community involvement.

A supporter of TIL stated that

"Yes. It is the local football club and is an important par of Tromsø's history and culture". And another:

\section{A Supporter of VIF stated}

"The use of the brand should always be united and aligned with the club's history, traditions, attitudes and identity. As such, it should be presented on healthy and "good" products that are not controversial and speculative."

c) Emotional Attachment

It was clear that respondents were affected by the emotional ties that bond them with their clubs. Their sense of identity, care and belonging help to maintain their relationships with the clubs. The emotional power of the clubs were obvious to marketing staff

"the club name immediately provokes an emotional reaction amongst those exposed to the brand name".

Similarly, supporter of VIF stated,

"I have an emotional attachment through a sense of belonging and community, as well as how and why I became a VIF supporter."

d) Brand Extension \& the Importance of Commercialisation for Football Clubs 
The final theme to emerge concerned the use of brand extensions and the commercialisation of football. The use of brand extensions emerged as a clear branding strategy for the clubs and VIF's marketing director discussed the exploitation of branded merchandise at length

“...we do get some criticism that we develop too many products ... [but] we must be allowed to develop new products and take advantage of the opportunities we have to become a larger club”.

And at TIL

"This [brand extension] is excellent for building our brand, and it makes our supporters feel a certain proximity to the club".

For fans, they support brand extension as one supporter of VIF stated,

"It [brand extension] strengthens the brand and loyalty to the club."

And a VIF supporter

"It helps spread the club's message and ensures that VIF stays at the top of people's minds. This leads to the club getting more supporters. You will see your belonging to the club everywhere, which is good."

Supporters are keen to see further commercialisation as they see its importance to the future success of their clubs. A supporter of TIL said,

"Yes, they should. They should establish a supporter retail shop in the city centre."

The above is a brief resume of some detailed qualitative research. It helped us to establish that these Norwegian clubs do consider themselves to be brands and that their branding strategies involve the development of brand extensions. The acceptance of branding and brand extensions by supporters is tested in the quantitative work detailed below. 


\section{Models Estimation}

Structural equation modelling (SEM) was employed. Using this technique has the advantages of dealing with multiple relationships among constructs simultaneously while ensuring statistical efficiency and it enables researchers to comprehensively assess the relationships in a systematic and holistic way (Hair et al., 1995). A confirmatory modelling approach using confirmatory factor analysis (CFA) was employed using LISREL (Joreskog and Sorbom, 1999). It is used to determine whether the collected data support the earlier categorisation of the indicators into measures of the constructs (Bagozzi, 1983). It can add to the results of the traditional techniques by testing the unidimensionality of a scale and "if necessary refining the factor structure found in exploratory factor analysis in order to ensure unidimensionality" (Steenkamp and Trijp, 1991, p. 287). In addition, the measurement model provides a confirmatory assessment of convergent validity and discriminant validity. The recent developments in marketing research strongly suggest that CFA is a more rigorous and precise test of unidimensionality as compared to traditional techniques such as exploratory factor analysis (EFA) (Gerbing and Anderson, 1988; Anderson and Gerbing, 1988; Steenkamp and Trijp, 1991).

The unidimensional test for constructs with reflective indicators was performed as suggested by Anderson and Gerbing (1982). This was done separately for each football club in order to ensure that each construct was defined correctly. In addition, composite reliability and variance extracted were calculated for all constructs and were above the threshold of .50 (Hair et al., 1995). Global fit indicators were used to evaluate the consistency of the measurement model (Sharma, 1996). The key indicators we used are Chi-Square $\left(X^{2}\right)$ divided by the Degree of Freedom, Comparative Fit Index (CFI) and the Goodness of Fit Index (GFI), Adjusted Goodness of Fit Index (AGFI) and Normed Fit Index (NFI).

\section{The Quantitative Findings}

Convergent validity was examined through establishing constructs' unidimensionality, except for brand strength which was measured using a single indicator. The unidimensionality for brand extension was achieved after deleting two items which had poor loading in both samples. As a result, brand extension was measured using four out of six items for both samples. The composite reliability and variance extracted were calculated for brand extension 
and brand emotion and all were above the threshold of .50 (Hair et al., 1995) except for the variance extracted for brand extension for the TIL sample which achieved $48 \%$, which was slightly below the threshold. Table 1 shows mean, standard deviations, composite reliability, variance extracted and factor loading for discriminant analysis for VIF and TIL.

Table 1 Mean, St. Deviations, Composite Reliability, Variance Extracted and EFA Discriminant Analysis.

\section{Emotional Attachment}

VIF/TIL: AVE $=51.3 / 53.6$

$\& \mathrm{CR}=.60 / .65$

I think the club is important for the city's culture.

I think the club has a rich history and tradition.

I think the club offers me an escape from everyday life.

I think the club's logo is important to its heritage and tradition.

Brand Strength

Brand Extension

VIF/TIL: AVE $=55.2 / 48.0$

$\& \mathrm{CR}=.73 / .63$

I like that the club offers branded products such as clothing, bags, key rings and towels.

I dislike the thought of the club as a brand in the same sense as Coca Cola, Telenor and Nike ${ }^{\circledR}$. I think of FIV/TIL as a brand in the same way as Coca Cola, Nike, Kvikk Lunsj and Telenor.

I would not like to see the club's name and logo on other products ${ }^{\circledR}$.

\begin{tabular}{|c|c|c|c|c|c|c|c|c|c|}
\hline \multicolumn{5}{|c|}{ VIF } & \multicolumn{5}{|c|}{ TIL } \\
\hline \multirow[t]{2}{*}{ Mean } & \multirow[t]{2}{*}{ S. D. } & \multicolumn{3}{|c|}{ Factor Loading } & \multirow[t]{2}{*}{ Mean } & \multirow[t]{2}{*}{ S. D. } & \multicolumn{3}{|c|}{ Factor Loading } \\
\hline & & $\begin{array}{l}\text { Emotional } \\
\text { Attach. }\end{array}$ & $\begin{array}{l}\text { Brand } \\
\text { Str. }\end{array}$ & $\begin{array}{c}\text { Brand } \\
\text { Ex. }\end{array}$ & & & $\begin{array}{c}\text { Emotional } \\
\text { Attach. }\end{array}$ & $\begin{array}{l}\text { Brand } \\
\text { Str. }\end{array}$ & $\begin{array}{c}\text { Brand } \\
\text { Ex. }\end{array}$ \\
\hline 4.64 & .663 & .772 & & & 4.69 & .624 & .595 & & \\
\hline 4.74 & .591 & .793 & & & 4.26 & .763 & .811 & & \\
\hline 3.27 & 1.178 & .585 & & & 3.35 & 1.21 & .642 & & \\
\hline 4.55 & .697 & .713 & & & 4.41 & .794 & .650 & & \\
\hline & & & .956 & & & & & .873 & \\
\hline 3.97 & 1.042 & .419 & & .560 & 3.85 & .997 & & & .781 \\
\hline 3.31 & 1.305 & & & .842 & 3.91 & 1.07 & & & .744 \\
\hline 3.21 & 1.390 & & & .814 & 3.21 & 1.26 & & & .579 \\
\hline 3.66 & 1.138 & & & .680 & 3.87 & 1.07 & & & .714 \\
\hline
\end{tabular}

Discriminant validity was also evident. All items loaded similarly in both samples to their underlying constructs except on item (I like that the club offers branded products such as clothing, bags, key rings and towels) which has insignificant cross loading for VIF sample. It 
has high loading on brand extension of .560 and low loading on emotional attachment of .419. This slight cross loading is not substantial enough to cause concern regarding discriminant validity. Table 2 shows the correlation matrix for VIF and TIL samples.

Table 2 Correlation Matrix for VIF and TIL.

\begin{tabular}{|l|c|c|c|}
\cline { 2 - 4 } \multicolumn{1}{c|}{} & Emotional Attachment & Brand Strength & Brand Extension \\
\hline Emotional Attachment & 1.00 & .378 & .228 \\
\hline Brand Strength & .422 & 1.00 & .448 \\
\hline Brand Extension & .323 & .466 & 1.00 \\
\hline
\end{tabular}

Note: Values above the diagonal are for the TIL sample; values below the diagonal are for the VIF sample. All correlations significant at $p<.01$

\section{Results}

The hypothesised links among constructs in the model were tested. The estimation of the model resulted in a very good fit for both samples. The goodness of fit indices for TIL show a very good fit with $\chi^{2}(\mathrm{df})=8.46(1), \mathrm{p}$-value $=.004, \mathrm{GFI}=.98, \mathrm{AGFI}=.93, \mathrm{CFI}=.97, \mathrm{NFI}=$ 96. The goodness of fit indices for VIF show an acceptable fit of the model with $\chi^{2}(\mathrm{df})=$ $7.01(1), \mathrm{p}$-value $=.02, \mathrm{GFI}=.98, \mathrm{AGFI}=.89, \mathrm{CFI}=.93, \mathrm{NFI}=.92$. The slight differences in the indices may be explained by the differing level of perceived benefits at the different clubs which can increase the emotional attachment and therefore influence brand strength and positive acceptance of brand extension. Nonetheless, these indices of fit show a very good fit of the model, which reflects the strength of the methodology used as well as the strength of the theoretical model. Table 2 shows the coefficient for each hypothesis and goodness of fit indices for the model for TIL and VIF.

Table 2 The Coefficients and Goodness of Fit Indicator for the Model

Estimate T-Value $\chi^{2}$ (df) P-Value GFI AGFI CFI

TIL

$\begin{array}{llll}8.46(1) \quad .004 \quad .98 & .93 \quad .97\end{array}$

Emotion Brand Strength

0.41

10.2

Brand Strength $\longrightarrow$ Brand Extension

0.51

VIF

$7.01(1)$

.02

.98

.89

.93

Emotion Brand Strength

0.28

10.4

Brand Strength $\longrightarrow$ Brand Extension

0.31

7.6 
To validate the above model, a rival model was tested. The rival model tested the relationship from 'brand strength' to 'brand emotion' and from 'brand emotion' to 'brand extension'. The result showed a rather poor fit for both samples. The goodness of fit indices for TIL show poor fit with $\chi^{2}(\mathrm{df})=93.2(1), \mathrm{p}$-value $=0.0, \mathrm{GFI}=.88, \mathrm{AGFI}=.33, \mathrm{CFI}=.61, \mathrm{NFI}=.60$. The result for VIF was slightly better but still poor compared to the original model with $\chi^{2}$ $(\mathrm{df})=63.2(1), \mathrm{p}$-value $=0.0, \mathrm{GFI}=.90, \mathrm{AGFI}=.40, \mathrm{CFI}=.52, \mathrm{NFI}=.53$. These results confirm that the original model reflects the reality within the data more accurately compared to the competing model.

\section{Discussion, Managerial Implications and Conclusion}

The results reported above indicate a strong link between all the constructs proposed in the original model, and both hypotheses are supported. The findings, as presented in the estimated model, show clearly that the stronger the supporters' emotional attachment to their club the stronger their perception of the club as a brand, contradicting the argument made by Chadwick and Holt (2006) and Chadwick and Beech (2007), that many supporters, despite their strong emotional attachment to the club, disapprove of the idea of their club as a brand. Supporters nowadays are no longer prisoners of emotional attachment to a historical club heritage only. These things are still very important; however, discussions with the clubs tell us that supporters understand the substantial increase in football competition and the fact that clubs need to increase their resources to improve and maintain their competitiveness. If there was increased on-field success paid for by increased commercial activity, then there may be a virtuous circle whereby the emotional attachment to the club by supporters also then increases. These findings are in line with the views taken by employees of the clubs that the clubs are indeed and should be, seen as commercial brands. H1 is therefore supported. Our results also demonstrate that the stronger supporters' perception of the brand, the more likely they would be to support brand extension, thereby also supporting $\mathrm{H} 2$.

Clearly the findings of this research illustrate a different understanding of football club supporters. At the core of this new understanding is supporters' orientation. While supporters have an orientation rooted in clubs' history and heritage, supporters also have an orientation focusing on future possible achievements and therefore are concerned with their club's 
competitiveness. It is this future orientation that helps supporters' perception of the club as a brand and it is also a driving force behind supporters' acceptance of brand extension. One supporter of VIF stated,

"The use of the brand should always be united and aligned with the club's history, traditions, attitudes and identity. As such, it should be [re]presented on healthy and "good" products that are not controversial and speculative."

In particular qualitative research indicated that the clubs were more keenly aware of the need to compete at a level of European competition and there was an acceptance amongst all stakeholders that greater professionalism and commercial orientation was needed to achieve success in Europe rather than just nationally. Fans are aware of the importance of commercial orientation that management of their clubs should aim at. A supporter of VIF stated,

"In sport today, you have to remain financially attractive to sponsors and it is important to me that the club continues to develop the non-sport related attitudes and values that are part of the club today."

Another supporter stated,

"Brand building will be important to keep the club alive and thrive in the future. Particularly in these days when corporate sponsorship is more difficult to get."

A supporter of TIL stated,

"Yes, in these days of financial hardship, I think they should extend the use of their brand to increase their revenues."

Although brand extension is something club supporters accept, club management needs to be careful when extending its brand. This is mainly because supporters want brand extensions to reflect and enhance the heritage of the club. Employees managing the brands talked of the importance of the clubs to their local areas and the sense of community and togetherness that the clubs fostered and the need to preserve this. As the Media Manager for VIF stated, 
"Vålerenga is not just something that happens every Sunday; it is a culture and whole life for many people, which we have to manage professionally and we have to focus on the responsibility we have."

For fans, they stressed the importance of maintaining the club's heritage and history when extending brand. One supporter of TIL stated,

"It is important that the club does not lose it sense of history and takes care of these values. They cannot sell the club's soul and spirit!"

Similarly, one supporter from VIF stated,

"as long as the club keeps to high-quality products that are aligned with both the club's and the supporters' values. Inappropriate and controversial products for the sake of revenues? No thank you!"

Avoiding the alienation of core supporters was deemed essential and it was stated that brand extensions were a key part of leveraging the history and traditions of the clubs, not just to reassure existing supporters but to educate younger fans in the tradition and history of the clubs. Statistical analysis of the data shows that supporters of both clubs rate the importance of their club to the city's culture highly and that they also believed that their clubs have a strong tradition and rich history. Thus any extension must be carefully designed; the perceived fit of the brand extension is a requirement of management focus. Similarly, club management needs to show in any brand extension an element of competitiveness which improves brand image, strengthens supporters' belief in their club and helps attract new supporters. Done correctly therefore, brand-building strategies can be used by football clubs to strengthen the bonds with their supporters. The implementation of such strategies needs to be based upon disciplined supporter segmentation and an in-depth knowledge of supporter motivations. By showing concern and due respect for the club's heritage and traditions, supporters concerns over the commercialisation of the club can be neutralised.

The importance of the clubs to their local communities was demonstrated during our research, and branding strategies should leverage their social commitment and responsibility to these communities. Local brands very often have a deep-rooted connection with local 
consumers, and leveraging secondary associations (Keller, 2003), such as the club's geographical origin and its history, can act as important connectors between the club and its supporters. The development of a broad youth section allowing children to play football under the umbrella of the clubs' brands is an example of the type of project that can strengthen connections between the club and its supporters. Such an association is likely to engender early loyalty to the club providing committed supporters (and buyers of the club's brand extensions) in future years.

The model shows that TIL's supporters have a greater emotional attachment to their club compared to VIF. This may be explained by the fact that TIL focuses only on football, very much bases itself as the heart of the geographical region that it comes from and is involved in promoting football at all levels within its community. Clearly the benefits to TIL's supporters are quite tangible compares to VIF which has different types of professional sports under its brand. It is much easier for TIL's supporters to connect emotionally with the club because they can see the benefits from brand extension for their club and for themselves as well.

\section{Conclusion}

This study has bridged a gap in the literature by investigated the branding of football clubs in a smaller European market - Norway. The study challenged the accepted argument that supporters of football clubs are likely to disapprove of and reject the thought of their favourite football club as a brand. Our findings found the opposite of this argument; that is, supporters accept their club as a brand and support brand extension and that there is a clear link between this acceptance of branding activity and supporters' emotional involvement with the club. It is evident that football clubs in smaller football nations can apply brand building strategies without sacrificing the authenticity of their clubs or their proximity to their supporters.

\section{References}

Aaker, D.A. and Keller, K.L. (1990), "Consumer evaluations of brand extensions", Journal of Marketing, Vol. 54 No. 1, pp. 27-41. 
Anderson, J. and Gerbing, D. (1988), "Structural equation modelling in practice: a review and recommended two-step approach”, Psychological Bulletin, Vol. 103 No. 3, pp. 411-423.

Apostolopoulou, A. (2002), "Brand extensions by U.S. professional sports teams: Motivations and keys to success”, Sport Marketing Quarterly, Vol. 11 No. 4, pp. 205-214.

Apostolopoulou, A. and Gladden, J.M. (2007), "Developing and extending sports brands". In: Beech, J. and Chadwick, S. (eds.), The Marketing of Sport, Pearson Education Ltd., Harlow, pp. 186-209.

Bagozzi, R. (1983), “A holistic methodology for modelling consumer response to innovation", Operations Research, Vol. 31 Jan.-Feb., pp. 128-176.

Bauer, H.H., Sauer, N.E. and Schmitt, P. (2005), "Customer-based brand equity in the team sport industry: operationalization and impact on the economic success of sports teams", European Journal of Marketing, Vol. 39 No. 5/6, pp. 496-513.

Biemacki, P. and Waldorf, D. (1981), "Snowball sampling: problems and techniques of chain referred sampling”, Social Methods and Research, Vol. 10 No. 2, pp. 141-163.

Bourke, A. (2006), "Marketing football in the Republic of Ireland". In: Desbordes, M. (ed.), Marketing and Football: An International Perspective, Oxford, Butterworth-Heinemann., pp. 237-373.

Bowlby, J. (1979), The Making and Breaking of Affectional Bonds, London: Tavistock.

Brassington, F. and Pettitt, S. (2004), Principles of Marketing, $3^{\text {rd }}$ ed., Pearson Education Ltd., Harlow.

Broniarczyk, S. and Alba, J. (1994), “The importance of the brand in brand extension”, Journal of Marketing Research, Vol. 31 No. 2, pp. 214-228.

Brown, S. (2003), “Postmodern marketing: Everything must go!”, In: Baker, M.J. (ed.), The Marketing Book, $5^{\text {th }}$ ed., Butterworth-Heinemann, Oxford, pp. 16-31. 
Brown, S., Kozinets, R.V. and Sherry, J.F. (2003), “Teaching old brands new tricks: Retro branding and the revival of brand meaning”, Journal of Marketing, Vol. 67 No. 3, pp. 19-33.

Boush, D. and Loken, B. (1991), "A process tracing study of brand extension evaluation”, Journal of Marketing Research, Vol. 28, Feb., pp. 16-28.

Calkins, T. (2003), “The challenge of branding”. In: The Economist (ed.), Brands and Branding, London, Profile Books Ltd., pp. 1-8

Carroll, B. and Ahuvia, A. (2006), "Some antecedents and outcomes of brand love", Marketing Letters, Vol. 17 No 2, pp. 79-89.

Chadwick, S. and Beech, J. (2007), "Introduction: The marketing of sport". In: Beech, J. and Chadwick, S. (eds.), The Marketing of Sport, Harlow, Pearson Education Ltd., pp. 3-22.

Chadwick, S. and Clowes, J. (1998), “The use of extension strategies by clubs in the English Football Premier League", Managing Leisure, Vol. 3 No. 4, pp. 194-203.

Chadwick, S. and Holt, M. (2006), "Building global sports brands: Key success factors in the marketing of the UEFA Champions League", In Desbordes, M. (ed.), Marketing and Football: An International Perspective, Oxford, Butterworth-Heinemann., pp. 22-50.

Cherubini, S. (2006), “Co-marketing: A new challenge for football managers", In Desbordes, M. (ed.), Marketing and Football: An International Perspective, Butterworth-Heinemann, Oxford, pp. 108-129.

Cialdini, R.B., Borden, R.J., Thorne, A., Walker, M.R., Freeman, S. and Sloan, L.R. (1976), "Basking in Reflected Glory: Three (football) field studies", Journal of Personality and Social Psychology, Vol. 34 No. 3, pp. 366-375.

Conn, D. (1998), The Football Business: Fair Game in the '90's, Mainstream Sport, London. Couvelaere, V. and Richelieu, A. (2005), "Brand strategy in professional sports: The case of 
French soccer teams”, European Sport Management Quarterly, Vol. 5 No. 1, pp. 23-46.

Creswell, J.W. (2007), Qualitative Inquiry and Research Design: Choosing Among Five Approaches, $2^{\text {nd }}$ ed., London, Sage Publications Ltd.

Dacin, P.A. and Smith, D.C. (1994) "The effect of brand portfolio characteristics on consumer evaluations of brand extensions", Journal of Marketing Research, Vol. 31 No. 2, pp. 229-242.

de Chernatony, L. (2003), "Brand building”, In Baker, M. J. (ed.), The Marketing Book, $5^{\text {th }}$ ed., Oxford, Butterworth-Heinemann., pp. 372-394.

de Chernatony, L. and McDonald, M.H.B. (2003), Creating Powerful Brands, $3^{\text {rd }}$ ed., Butterworth-Heinemann, Oxford,

Desbordes, M. (ed.) (2006), Marketing and Football: An International Perspective, Butterworth-Heinemann, Oxford,

Elliot, R. and Percy, L. (2007), Strategic Brand Management, Oxford University Press, Oxford.

Ferrand, A. and Pages, M. (1999), "Image management in sports organisation”, European Journal of Marketing, Vol. 33 No. 3/4, pp. 387-401.

Fisher, R.J. and Wakefield, K. (1998), "Factors leading to group identification: A field study of winners and losers", Psychology and Marketing, Vol. 15 No. 1, pp. 23-41.

Fournier, S. (1998), "Consumers and their brands: developing relationsip theory in consumer research, Journal of Consumer Research, Vol. 24 No. , pp 343-373.

Gerbing, D. and Anderson, J. (1988), “An updated paradigm for scale development incorporating unidimensionality and its assessment", Journal of Marketing Research, Vol. 85 No. 2, pp. 186-192. 
Gladden, J.M., Sutton, G.R. and Milne, W.A. (1998), “A conceptual framework for assessing brand equity in Division I college athletics", Journal of Sport Management, Vol. 12 No. 12, pp. 1-19.

Guenzi, P. and Nocco, M. (2006), "The launch of new brands by professional soccer teams", International Journal of Sports Marketing \& Sponsorship, Vol. 7 No. 3, pp. 251-267.

Hair, J., Anderson, R., Tatham, R. and Black, W. (1995). Multivariate Data Analysis With Readings, 4th Ed., Prentice-Hall, New Jersey, NJ.

Hill, J.S. and Vincent, J. (2006), "Globalisation and sports branding: The case of Manchester United”, International Journal of Sports Marketing \& Sponsorship, Vol. 7 No. 3, pp. 213231.

Hunt, K.A., Bristol, T. and Bashaw, R.E. (1999), “A conceptual approach to classifying sports fans", Journal of Services Marketing, Vol. 13 No. 6, pp. 439-452.

Jones, I. (1997), "A further examination of the factors influencing current identification with a sports team, a response to Wann et al. (1996)", Perceptual and Motor Skills, Vol. 85 No. 1, pp. 257-258.

Joreskog, K. and Sorbom, D. (1999), Interactive LISREL: User's Guide, Scientific Software International, Chicago.

Kapferer, J.N. (1997), Strategic Brand Management, $2^{\text {nd }}$ ed., Kogan Page Ltd., London.

Kapferer, J. N. (2001), Re-inventing the Brand: Can Top Brands Survive the New Market Realities?, Kogan Page Ltd., London.

Kapferer, J.N. (2002), "Is there really no hope for local brands?", Journal of Brand Management, Vol. 9 No. 3, pp. 163-170.

Keller, K. L. (2003), Strategic Brand Management - Building, Measuring, and Managing Brand Equity, $2^{\text {nd }}$ ed., Prentice Hall, Upper Saddle River, NJ. 
Keller, K. L. (2003), “Conceptualizing, measuring, and managing customer-based brand equity”, Journal of Marketing, Vol. 40 No. 7/8, pp. 1-22.

Keller, K. L. and Aaker, D. (1992), "The effects of sequential introduction of brand extensions", Journal of Marketing Research, Vol. 29 Feb., pp. 35-50.

Malhotra, N. K. and Birks, D. F. (2006), Marketing Research - An Applied Approach, $2^{\text {nd }}$ ed., Pearson Education Ltd., Harlow.

Martínez, E. and de Chernatony, L. (2004), "The effect of brand extension strategies upon brand image", Journal of Consumer Marketing, Vol. 21 No. 1, pp. 39-50.

Mason, D. (1999), "What is the sports product and who buys it? The marketing of professional sports leagues", European Journal of Marketing, Vol. 33 No. 3/4, pp. 402-418.

McWilliam, G. (1993), "The effect of brand typology on brand extension fit: commercial and academic research findings", European Advances in Consumer Research, Vol. 1, pp. 485-491.

Miles, M. B. and Huberman, A. M. (1994), Qualitative Data Analysis: A Sourcebook for New Methods, $2^{\text {nd }}$ ed., Sage Publications, Thousand Oaks (CA)

Mullin, B., Hardy, S. and Sutton, W.A. (2000), Sport Marketing, $2^{\text {nd }}$ ed., Human Kinetics, Champaign (Il).

Noble, J. (2006), "Branding: From a commercial perspective", Journal of Brand Management, Vol. 13 No. 3, pp. 206-214.

Park, W. and Macinnis, D. (2006), "What's in and what's out: questions on the boundaries of the attitude construct", Journal of Consumer Research, Vol. 33 June, pp.16-18. 
Parker, K. and Trish, S. (1997) "The West Ham syndrome: Comparison between loyalty to football clubs and brand loyalty", Journal of Market Research Society, Vol. 39 No. 3, pp. $509-518$.

Pons, F. and Standifird, S. (2006), "Marketing of professional soccer in the US: Some lessons to be learned". In Desbordes, M. (ed.), Marketing and Football: An International Perspective, Butterworth-Heinemann, Oxford, pp. 395-414.

Reast, J. (2005), "Brand trust and brand extension acceptance: the relationship", Journal of Product \& Brand Management, Vol. 14 No. 1, pp. 4-13.

Rein, I., Kotler, P. and Ryan, S.B. (2006), The Elusive Fan: Reinventing Sports in a Crowded Marketplace, McGraw-Hill Higher Education, New York, NY.

Roper, S. and Davies, G. (2007), "The corporate brand; dealing with multiple stakeholders", Journal of Marketing Management, Vol 23 No 1-2, pp. 75-90.

Ross, S. D. (2006), “A conceptual framework for understanding spectator-based brand equity”, Journal of Sport Management, Vol. 20 No. 1, pp. 22-38.

Ruth, J. (2001), "Promoting a brand's emotion benefits: the influence of emotion categorization processes on consumer evaluations", Journal of Consumer Psychology, Vol. 11 No. 2, pp. 99-113.

Sharma, S. (1996), Applied Multivariate Techniques. John Wiley, New York.

Steenkamp, J. and Trijp, H. (1991). "The use of LISREL in validating marketing construct", International Journal of Research in Marketing, Vol. 8 No. 4, pp. 283-299.

Sutton, W.A., McDonald, M.A. Milne, G.R. and J. Cimperman (1997), "Creating and fostering fan identification in sports", Sports Marketing Quarterly, Vol. 6 No. 1, pp. 15-22.

Tapp, A. and Clowes, J. (2002), "From 'Carefree Casuals' to 'Professional Wanderers': segmentation possibilities for football”, European Journal of Marketing, Vol. 36 No. 11/12, 
pp. 1248-1269.

Thomson, M., MacInnis, D. and Park, W. (2005), "The ties that bind: measuring the strength of consumers' emotional attachments to brand", Journal of Consumer Psychology, Vol. 15 No. 1, pp. 77-91.

Tybout, A.M. and Sternthal, B. (2003), "Brand positioning”. In Tybout, A.M. and Calkins, T. (eds.), Kellogg on Branding, John Wiley \& Sons Ltd, Hoboken, NJ, pp. 11-26.

Underwood, R., Bond, E. and Baer, R. (2001), "Building service brands via social identity: Lessons from the sports marketplace", Journal of Marketing Theory and Practice, Vol. 9 No. 1, pp. 1-13.

Wann, D.L. and Branscombe, N.R. (1993), "Sports fans: Measuring degree of identification with their team”, International Journal of Sports Psychology, Vol. 24 No. 1, pp. 1-17.

Webb, J.R. (2003), “Marketing research”. In Baker, M.J. (ed.) (2003), The Marketing Book, $5^{\text {th }}$ ed., Butterworth-Heinemann, Oxford, pp. 171-196.

Westerbeek, H. and Smith, A. (2003), Sport Business in the Global Marketplace, Palgrave New York, NY.

Whannel, G. (1992), Fields in Vision: Television Sport and Cultural Transformation, London, Routledge. 